\title{
KONSEP DESAIN PENGEMBANGAN KAWASAN TOD PADA KAWASAN RAWAN BENCANA ROB, STUDI KASUS STASIUN SEMARANG TAWANG
}

\section{DESIGN CONCEPT OF TOD DEVELOPMENT FOR ROB DISASTER PRONE AREA, CASE STUDY SEMARANG TAWANG STATION}

\author{
Dwi Abad Tiwi \\ Pusat Teknologi Reduksi Risiko Bencana, TPSA-BPPT \\ Gedung Geostech It 1, Komplek PUSPIPTEK-Serpong, Tangerang Selatan \\ email: dabadtiwi@gmail.com; HP: 0811169215
}

\begin{abstract}
The concept development of Transit Oriented Development (TOD) area is new in Indonesia. Based on experience abroad, 4 kinds of concepts for developing TOD Areas have been recognized, namely Regional Scale, Corridor Scale, Station Area Scale and Site Scale. The Ministerial Regulation ATR-BPN Number 16 of year 2017 regarding Guidance for the Development of TOD has also accommodated several criteria and indicators for the development of the TOD Area. The existence of the northern Semarang city area that is always experiencing rob threat causes the rate of land decline by ranging from the lowest \pm $2.18 \mathrm{~cm}$, and the highest $\pm 21.33 \mathrm{~cm}$ over a period of four years (2013-2017). Rob's threat to Semarang Tawang Station Area has been anticipated by PT. KAl plans to raise the railway from Ahmad Yani Airport to Alas Purwo in the east of Semarang City. The development of TOD area design concept for the northern city of Semarang requires various considerations for adjustment as a rob disaster prone area.
\end{abstract}

Keywords: TOD development design concept, Semarang-Tawang Station

\begin{abstract}
ABSTRAK
Konsep pengembangan kawasan Transit Oriented Development (TOD) merupakan hal baru di Indonesia. Berdasarkan pengalaman di luar negeri, telah dikenal 4 macam konsep pengembangan Stasiun dan Kawasan TOD, yaitu Skala Regional, Skala Koridor, Skala Area Stasiun, dan Skala Tapak. Peraturan Menteri ATR-BPN Nomor 16 tahun 2017 tentang Pedoman Pengembangan Kawasan Berorientasi Transit juga sudah mengakomodasi beberapa kriteria dan indikator untuk pengembangan Kawasan $T O D$. Keberadaan kawasan Kota Semarang bagian utara yang selalu mengalami ancaman rob menyebabkan terjadinya laju penurunan muka tanah yang berkisar terendah $\pm 2,18 \mathrm{~cm}$, dan tertinggi $\pm 21,33 \mathrm{~cm}$ selama kurun waktu empat tahun (2013-2017). Ancaman rob pada Kawasan Stasiun Semarang Tawang telah diantisipasi oleh PT. KAI dengan merencanakan untuk menaikkan level rel kereta api mulai dari Bandara Ahmad Yani sampai dengan Alas Purwo di sebelah timur Kota Semarang. Pengembangan konsep desain kawasan TOD untuk Kota Semarang bagian utara memerlukan berbagai pertimbangan untuk penyesuaian sebagai kawasan rawan bencana rob.
\end{abstract}

Kata kunci: konsep desain pengembangan $T O D$, Stasiun Semarang Tawang 


\section{LATAR BELAKANG}

\subsection{Pengembangan Desain Kawasan TOD 1.1.1. Konsep Desain}

Pengembangan Konsep Desain Kawasan Transit Oriented Development (TOD) merupakan hal baru di Indonesia. Berdasarkan pengalaman di luar negeri, telah dikenal 4 macam konsep pengembangan stasiun dan kawasan $T O D$, yaitu Skala Regional, Skala Koridor, Skala Area Stasiun, dan Skala Tapak sebagai berikut (National Academies of Sciences, Engineering, and Medicine, 2004).

a. Skala Regional adalah pengembangan kawasan TOD berdasarkan beberapa koridor di suatu kota atau wilayah secara terpadu, dengan membuat jaringan tempat dan lokasi transit yang mengintegrasikan berbagai fungsi dan pusat aktivitas dalam suatu akses transit angkutan massal secara mudah.

b. Skala Koridor adalah pengembangan kawasan TOD pada suatu koridor wilayah dari beberapa stasiun yang berdekatan, di mana secara bersamasama mendukung konektivitas antar stasiun dan moda transportasi angkutan massal.

c. Skala Area Stasiun adalah pengembangan kawasan $T O D$ dalam radius $1 / 2$ mil atau $1 \mathrm{~km}$ di sekitar suatu stasiun, dimungkinkan untuk penggunaan lahan campuran dan mendukung akses transit angkutan massal, dengan mempertimbangkan kondisi lingkungan

d. Skala Tapak adalah pengembangan kawasan $T O D$ dalam wilayah stasiun kereta api itu sendiri, yang dimungkinkan untuk penggunaan lahan campuran perumahan dan jasa, serta mendukung akses transit dari transportasi angkutan massal.

\subsubsection{Peraturan Menteri ATR-BPN No $16 / 2017$}

Konsep pengembangan Kawasan $T O D$ telah diatur dalam Peraturan Menteri ATR-BPN No. 16 Tahun 2017 tentang Pedoman Pengembangan Kawasan Berorientasi Transit, dan diamanatkan kriteria untuk pemilihan lokasi potensial pengembangan $T O D$ sebagai berikut:

a. berada pada simpul transit jaringan angkutan umum massal berkapasitas tinggi; b. memenuhi persyaratan intermoda dan antarmoda transit;

c. dilayani paling kurang 1 (satu) moda transit jarak dekat dan 1 (satu) moda transit jarak jauh;

d. sesuai dengan arah pengembangan pusat pelayanan dan kegiatan;

e. berada pada kawasan dengan kerentanan bencana rendah disertai mitigasinya; dan

f. berada pada kawasan yang tidak mengganggu instalasi penting negara.

Sedangkan kriteria yang bisa dipakai dalam pemilihan lokasi potensial:

a. sesuai rencana tata ruang sebagai kawasan campuran perumahan dan jasa,

b. mendukung akses transit sebagai bagian dari sistem transportasi angkutan massal,

c. mendukung fungsi simpul keterhubungan antar berbagai moda transportasi,

d. ketersediaan lahan pengembangan baru berupa kawasan campuran,

e. memiliki peluang menumbuhkan daya beli masyarakat melalui pengembangan berkepadatan tinggi dan campuran.

\subsection{Konsep Pengembangan Kawasan TOD Stasiun Semarang Tawang}

Dari keempat konsep model pengembangan Kawasan $T O D$ di atas, dan berdasarkan Permen ATR-BPN No. 16/2017, maka untuk pengembangan kawasan $T O D$ Stasiun Semarang Tawang telah dipilih konsep pengembangan dengan model Skala Area Stasiun berdasarkan pertimbangan berikut.

a. Kelebihan

- Dimungkinkan memanfaatkan lahan milik pemerintah PT. KAl atau Kementerian Perhubungan untuk dikerjasamakan.

- Dimungkinkan menerapkan konsep partisipasi pemerintah, swasta, dan masyarakat dalam penataan ruang dan pembangunan kawasan.

b. Potensi untuk dikerjasamakan

- Swasta:

- Perbaikan stasiun dan pembangunan infrastruktur jalan penghubung dan jembatan penyeberangan

- Pembangunan pada kawasan radius I km di luar stasiun untuk 


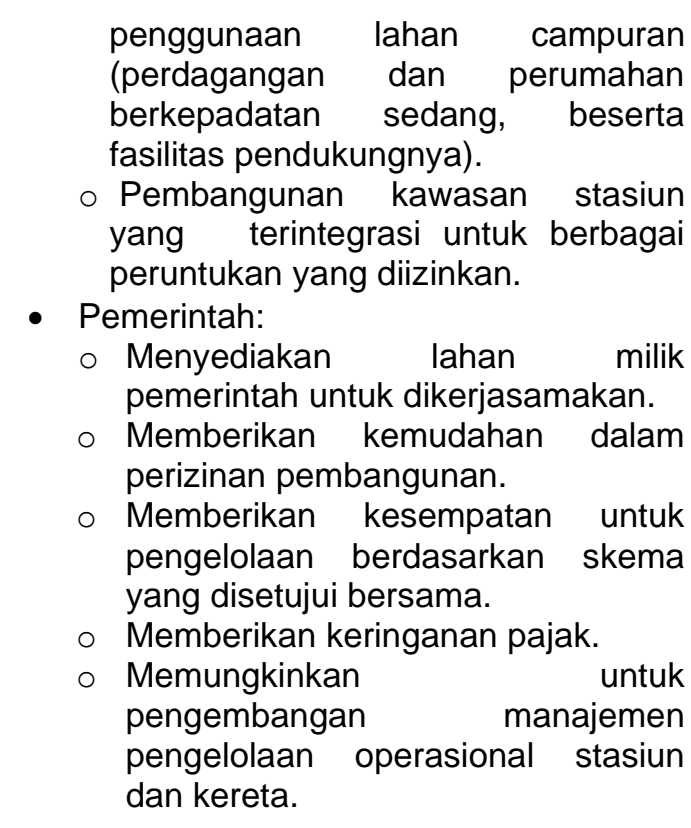

\section{METODOLOGI}

Metodologi yang dipakai untuk analisis pengembangan konsep desain Kawasan $T O D$ Stasiun Semarang Tawang sebagai berikut:

- Tahap I. Penetapan Konsep Dasar Pengembangan Kawasan TOD

Pada tahap ini dilakukan analisis referensi untuk pengembangan konsep pembangunan kawasan $T O D$

- Tahap II. Analisis Kondisi Eksisting Stasiun

Berisi analisis kondisi eksisting stasiun yang meliputi penggunaan lahan dan aksesibilitas, perumusan konsep pemanfaatan lahan dan adanya keterbatasan rawan bencana rob, serta analisis kegiatan dan kebutuhan ruang.

- Tahap III. Analisis Pengembangan Desain Stasiun

Berisi analisis pengembangan desain stasiun berdasarkan kebutuhan ruang, hambatan dan keterbatasan dalam pemanfaatan lahan.

Tahap IV. Perumusan Desain Stasiun dan Kawasan TOD beserta model Kerjasamanya.

Berdasarkan analisis pengembangan desain stasiun, dilakukan perumusan konsep desain stasiun dan Kawasan TOD untuk Stasiun Semarang Tawang. Selain itu juga dirumuskan potensi kerjasama pengembangannya dengan pihak pemerintah dan swasta.



\section{Gambar 1. Metodologi Pengembangan Konsep}

(Sumber: Hasil Analisis 2017)

\section{HASIL PEMBAHASAN}

\subsection{Kondisi Eksisting Penggunaan Lahan Stasiun Semarang Tawang}

Penggunaan lahan di sekitar Stasiun Semarang Tawang pada saat ini selain untuk Stasiun, sebelah utara dipakai untuk permukiman dan pergudangan, sebelah selatan kolam polder untuk penampungan air, sebelah timur dimanfaatkan untuk penggunaan campuran permukiman, pendidikan, dan jasa perdagangan. Di sebelah barat dimanfaatkan untuk penggunaan campuran perkantoran, permukiman dan jasa perdagangan.

\subsection{Kondisi Aksesibilitas}

Aksesibilitas utama menuju Stasiun Semarang Tawang adalah melalui Jl. Tawang yang berada di depan Stasiun, jalan satu arah dengan kondisi ramai, bukan merupakan jalan perlintasan. Jalan ini dicapai dari arah utara melalui Jl. Empu Tantular menuju Jl. Tawang dan Jl. Merak, dan dari Jl. Ronggowarsito menuju Jl. Pengapon. Dari arah barat melalui Jl. Bandarharjo Selatan dan Jl. Kolonel Sugiono menuju Jl. Tawang. Dari arah timur dicapai dari JI. Pengapon dan JI. Raden Patah menuju Jl. Tawang, dan dari arah selatan dicapai melalui Jl. Cenderawasih menuju JI. Tawang.

\subsection{Kondisi Ancaman Rob}

Keberadaan kawasan Kota Semarang utara yang selalu mengalami ancaman rob menyebabkan terjadinya laju penurunan muka 
tanah Kota Semarang utara berkisar terendah $\pm 2,18 \mathrm{~cm}$, dan tertinggi $\pm 21,33 \mathrm{~cm}$ selama kurun waktu empat tahun (2013-2017) (Kasfari et al., 2017). Ancaman rob ini diantisipasi oleh Pihak PT. KAI sementara ini dengan memanfaatkan lahan yang berada di sebelah selatan sebagai kolam polder dan di sebelah timur sebagai kolam penampungan air. Pengembangan Kawasan TOD di sekitar Stasiun Semarang Tawang memungkinkan untuk dilakukan dengan mempergunakan bangunan dengan kedalaman pondasi yang mencapai tanah keras. Selain itu, pihak PT. $\mathrm{KAI}$ telah melakukan kajian rencana peninggian jalur rel kereta api mulai dari Bandara Ahmad Yani ketimur sampai dengan Alas Purwo (Dirjen Perkeretapian, 2013).

Gambar 2, 3 dan 4 berikut memperlihatkan kondisi pemanfaatan lahan dan aksesibilitas menuju Stasiun Semarang Tawang.

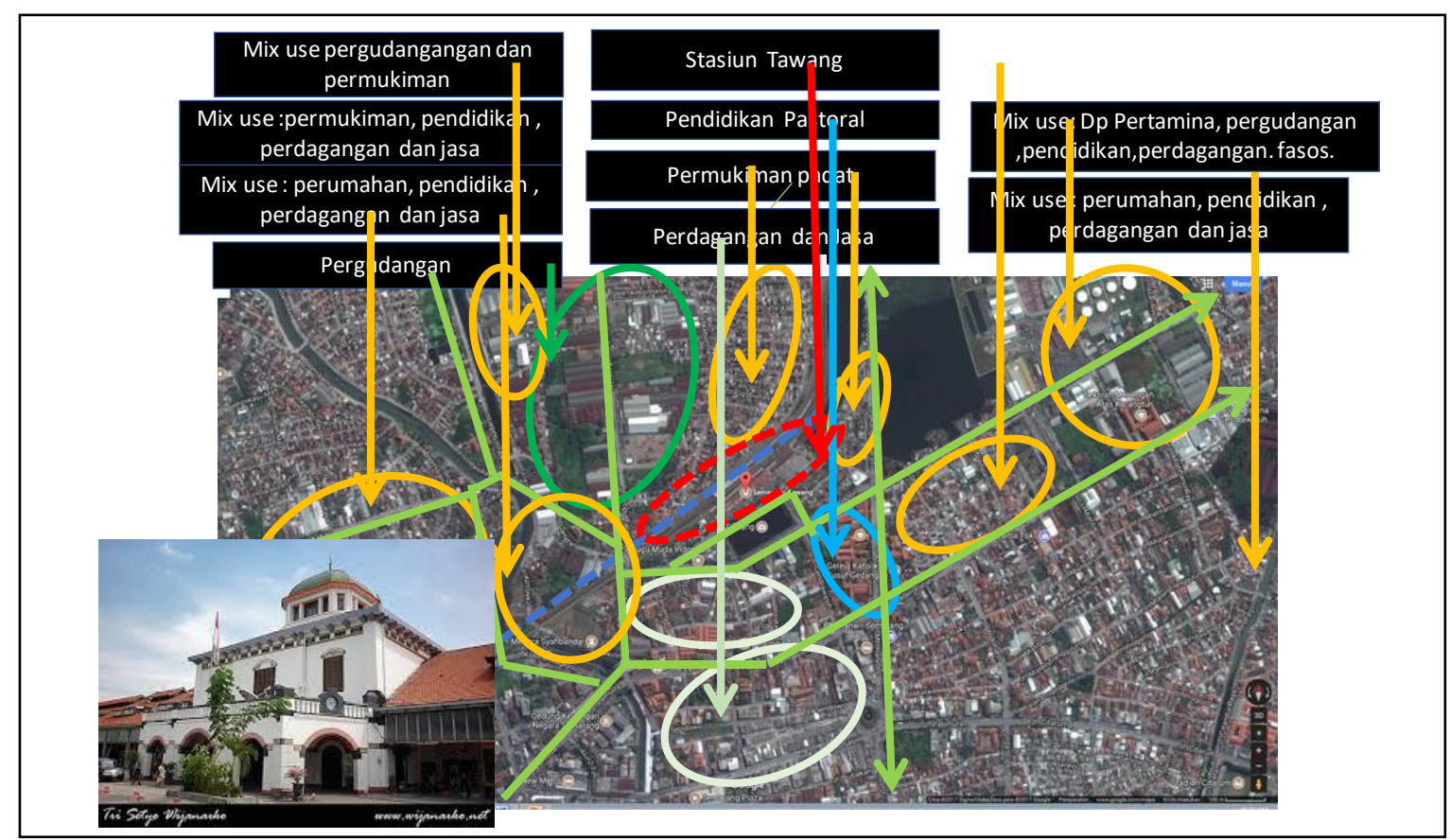

Gambar 2. Peta Kondisi Penggunaan Lahan

(Sumber: Hasil Analisis 2017)

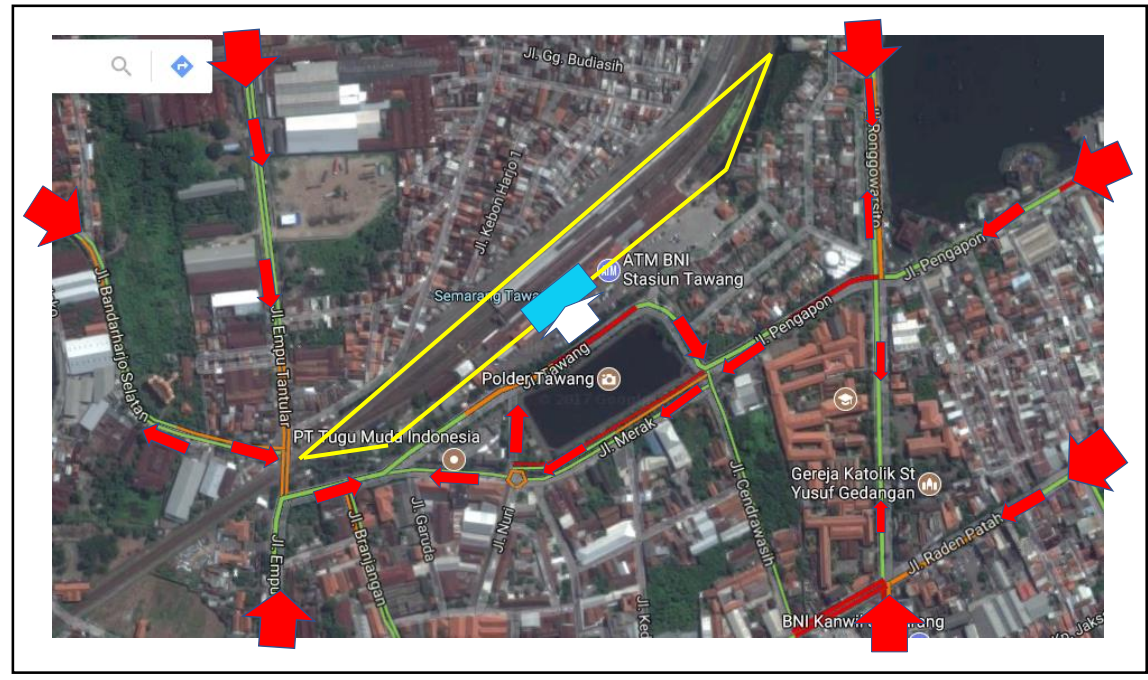

Gambar 3. Peta Aksesibiltas Menuju Stasiun Semarang Tawang

(Sumber: Hasil Analisis 2017) 


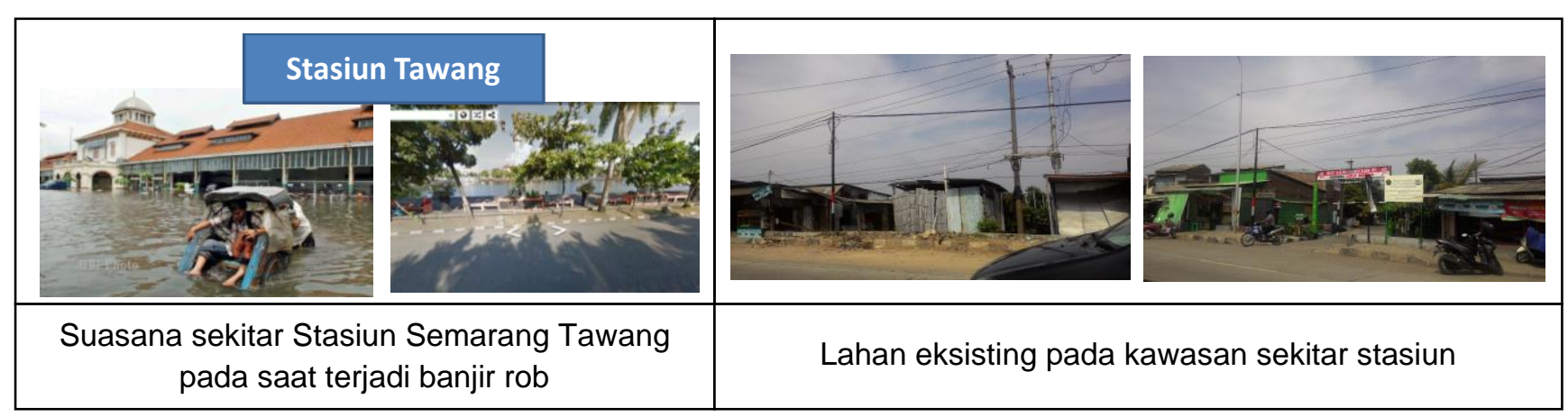

Gambar 4. Penggunaan Lahan Eksisting Sekitar Stasiun Semarang Tawang

(Sumber : Hasil Analisis Tahun 2017)

\subsection{Potensi Pemanfaatan Lahan}

Kawasan di sekitar Stasiun Semarang Tawang yang berpotensi untuk dikerjasamakan adalah:

a. Lahan milik PT. KAl yang berada di sebelah utara timur stasiun, dengan pertimbangan tidak akan mengganggu keberadaan kawasan heritage Stasiun Semarang Tawang.

b. Pemanfaatan lahan yang berlokasi di sebelah utara timur stasiun dan berada di sepanjang JI Ronggowarsito di kawasan ini merupakan kegiatan campuran permukiman, pergudangan, perdagangan dan jasa, serta kolam penampungan genangan air.

c. Juga akan dikerjasamakan lahan di sebelah timur selatan stasiun yang saat ini merupakan kegiatan campuran permukiman, perdagangan dan jasa.

\section{KONSEP DISAIN}

\subsection{Konsep Pemanfaatan Lahan}

Dengan melihat berbagai analisis di atas, maka konsep pemanfaatan lahan Kawasan TOD Stasiun Semarang Tawang adalah sebagai berikut:

a. Lahan-lahan di sekitar dan lahan Stasiun Semarang Tawang akan direncanakan secara terintegrasi menjadi suatu kawasan $T O D$, dengan pemanfaatan bangunannya diperuntukkan untuk pergudangan, perdagangan dan jasa, dan perkantoran.

b. Untuk bangunan stasiunnya, selain untuk kegiatan stasiun diperuntukkan juga untuk fasilitas penunjang, seperti retail dan jasa perdagangan. Berdasarkan Rencana Detil Tata Ruang (RDTR) Kecamatan Tanjung Mas Tahun 2014-2034, kawasan Stasiun Semarang Tawang dan sekitarnya direncanakan untuk kegiatan transportasi utama yaitu kereta api beserta kegiatankegiatan penunjangnya. Sehingga perencanaan Kawasan TOD Stasiun Semarang Tawang sudah sesuai dengan RDTR Kecatamatan Tanjung Mas Tahun 2014-2034.

Dengan perencanaan Kawasan $T O D$ Stasiun Semarang Tawang yang terintegrasi dalam suatu kesatuan dimaksudkan memberikan kesempatan untuk memanfaatkan bangunan sekitar sebagai akses masuk Stasiun Semarang Tawang sekaligus untuk pengaturan aksesibilitas menuju stasiun. Satusatunya aksesibilitas adalah dengan memanfaatkan Jalan Pengapon dan Jalan Tawang sebagai akses lama masuk ke Stasiun Semarang Tawang. Sedangkan aksesibilitas menuju kawasan TOD adalah dengan memanfaatkan Jl. Ronggowarsito yang dalam RDTR Kecamatan Tanjung Mas mempunyai lebar 30m, dan Jalan Pengapon yang direncanakan mempunyai lebar $30 \mathrm{~m}$.

\subsection{Perkiraan Kebutuhan Ruang \\ 4.2.1. Standar Kebutuhan Bangunan Kereta Api}

Standar yang dipakai untuk perhitungan kebutuhan ruang adalah mengacu kepada:

a. Peraturan Menteri Perhubungan RI No PM.29 Tahun 2011 tentang Persyaratan Teknis Bangunan Stasiun Kereta Api.

b. Peraturan Menteri Perhubungan RI No PM.48 Tahun 2015 tentang Standard Pelayanan Minimum Angkutan Orang dengan Kereta Api

Dengan asumsi jumlah penumpang maksimum untuk kereta cepat JakartaSurabaya maka diperkirakan kapasitas daya tampung stasiun yang dibutuhkan pada suatu saat untuk Stasiun Semarang Tawang adalah 500 orang. 


\subsubsection{Pengembangan Aksesibilitas dan Sirkulasi}

Aksesibilitas utama menuju Stasiun Semarang Tawang satu-satunya adalah melalui Jl. Tawang yang berada di depan Stasiun Semarang Tawang, yaitu jalan satu arah dengan kondisi ramai, bukan merupakan jalan perlintasan. Aksesibilitas penumpang kereta menuju dan dari Stasiun Semarang Tawang dapat dilakukan melalui:

a. Moda kendaraan pribadi yang hanya menurunkan penumpang atau parkir

b. Moda kendaraan umum yang berbasis jalan raya seperti bus umum, bus.

Dengan keberadaan kawasan heritage di daerah tersebut yang tidak memungkinkan untuk melakukan pelebaran jalan dan mengantisipasi besarnya calon penumpang kereta pada kurun waktu perencanaan 50 tahun ke depan, maka diperlukan perencanaan moda transportasi berbasis rel yang secara reguler menghubungkan wilayah-wilayah di dalam kota Semarang dan dari kota terdekat.

Fasilitas parkir utama akan berada di depan stasiun, dimana terdapat 2 pintu keluar dan masuk ke Stasiun Semarang Tawang, yaitu:

a. Dari parkir utama yang berada di depan satasiun menuju pintu masuk yang berada di lantai satu, seperti kondisi sekarang ini.

b. Dari parkir utama, dengan jembatan penyeberangan langsung menuju lantai 2 Stasiun.

Gambar berikut menunjukkan konsep pemanfaatan lahan pada Kawasan TOD Stasiun Semarang Tawang.

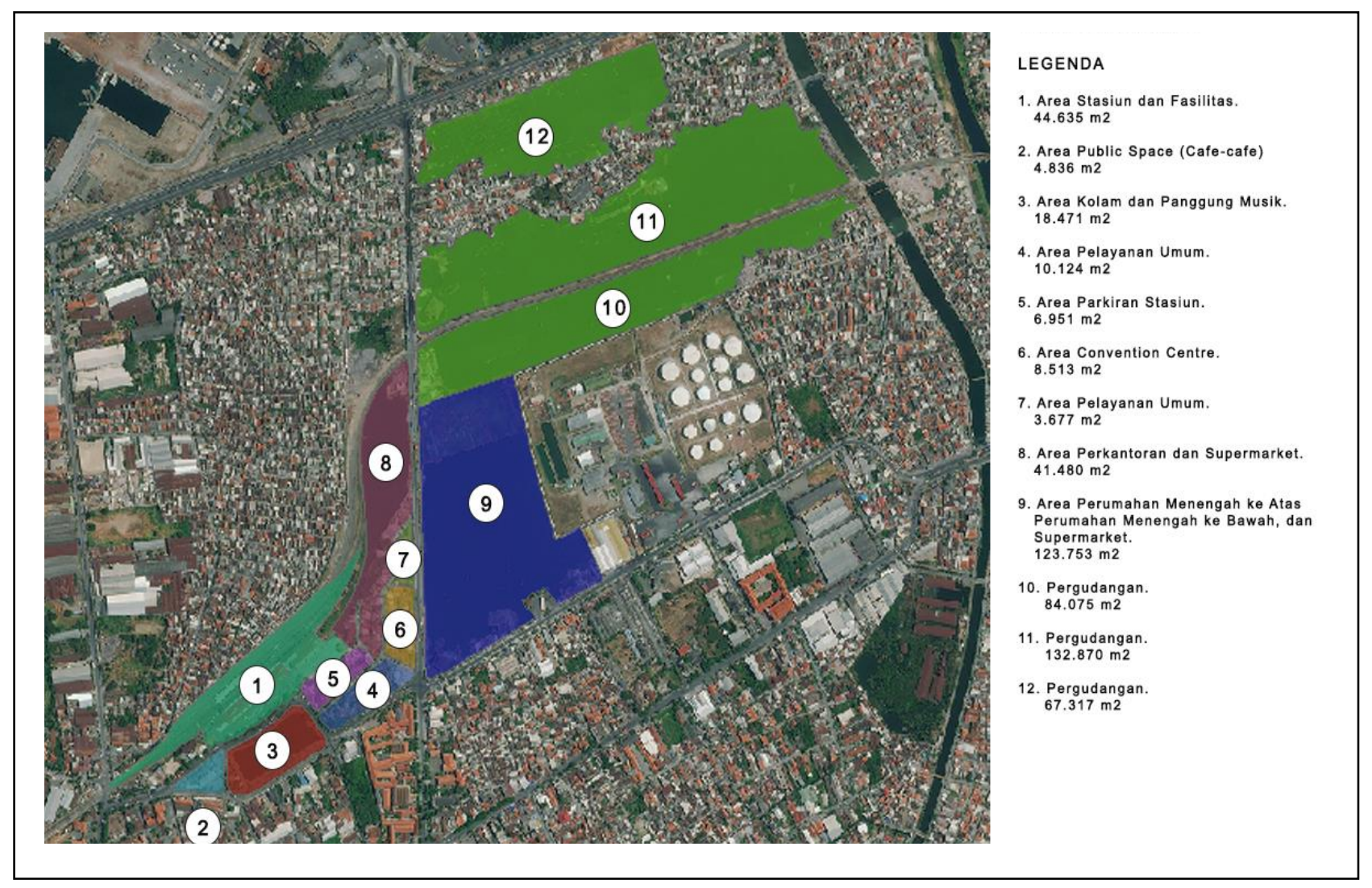

Gambar 5: Konsep Desain Pemanfaatan Lahan Kawasan TOD Semarang Tawang (Sumber: Hasil Analisis 2017) 


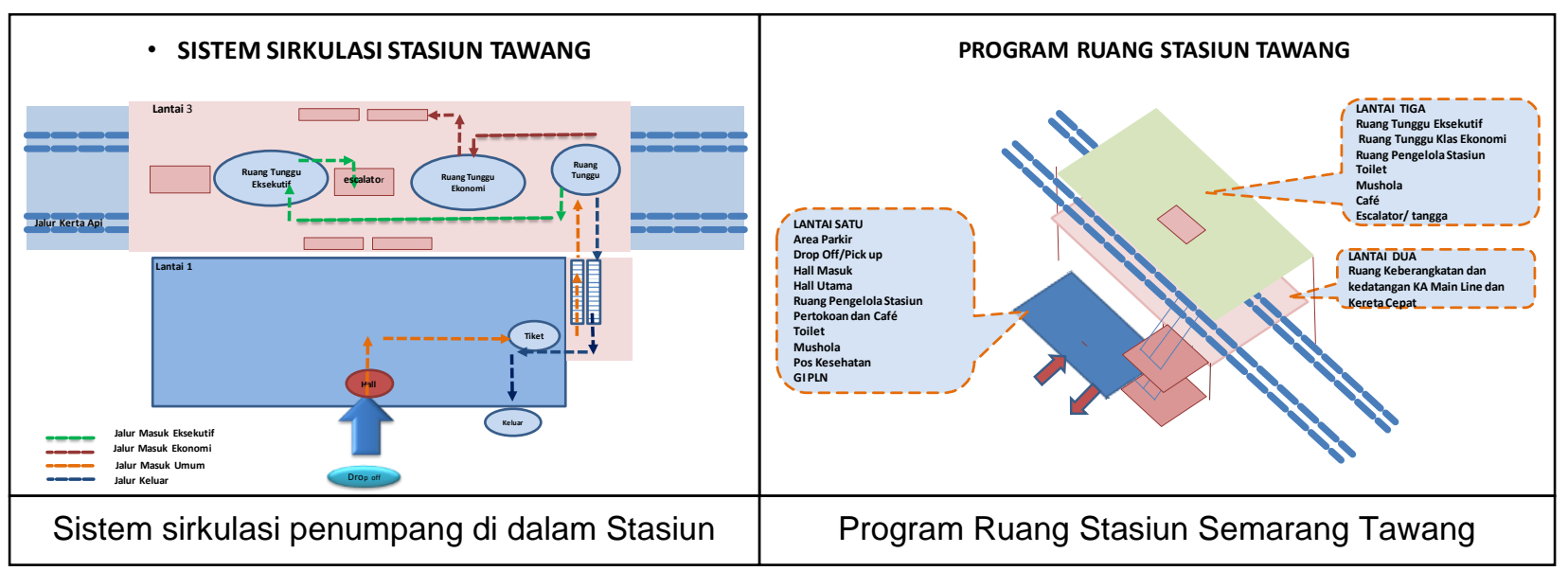

Gambar 6. Sistem Sirkulasi dan Program Ruang Stasiun Semarang Tawang. (Sumber: Hasil Analisis 2017)

\subsubsection{Kawasan TOD Stasiun Semarang Tawang}

Berdasarkan persyaratan teknis bangunan stasiun kereta api yaitu Peraturan Menteri Perhubungan RI No PM.29 Tahun 2011 tentang Persyaratan Teknis Bangunan Stasiun Kereta Api, dan ketersediaan luas lahan beserta peraturan Koefisien Dasar Bangunan (KDB), maka didapatkan potensi pemanfaatan ruang pada Kawasan $T O D$ Setasiun Semarang Tawang sebagai berikut.

Tabel 1. Potensi Pemanfaatan Ruang pada Kawasan TOD Stasiun Semarang Tawang

\begin{tabular}{llccccc}
\hline No & \multicolumn{1}{c}{ Pemanfaatan Ruang } & $\begin{array}{c}\text { Luas } \\
\text { Lahan }\end{array}$ & KDB & $\begin{array}{c}\text { Luas } \\
\text { Bangunan } \\
\text { Maksimum }\end{array}$ & $\begin{array}{c}\text { Ketinggian } \\
\text { Bangunan } \\
\text { Maksimum }\end{array}$ & $\begin{array}{c}\text { Luas } \\
\text { Bangunan } \\
\text { Total }\end{array}$ \\
\hline 1 & Stasiun dan Fasilitas & 44,635 & 0.60 & 26,781 & 2 & 53,562 \\
\hline 2 & Ruang publik/café & 4,836 & 0.60 & 2,902 & 2 & 5,803 \\
\hline 3 & $\begin{array}{l}\text { Kolam/folder dan panggung } \\
\text { musik }\end{array}$ & 18,471 & 0.60 & 11,083 & & - \\
\hline 4 & Pelayanan umum & 10,124 & 0.60 & 6,074 & 2 & 12,149 \\
\hline 5 & Parkir stasiun & 6,951 & 0.60 & 4,171 & 2 & 8,341 \\
\hline 6 & Convension centre & 8,513 & 0.60 & 5,108 & 3 & 15,323 \\
\hline 7 & Pelayanan umum & 3,677 & 0.60 & 2,206 & 2 & 4,412 \\
\hline 8 & Perkantoran dan supermarket & 41,480 & 0.60 & 24,888 & 5 & 124,440 \\
\hline 9 & $\begin{array}{l}\text { Perumahan menengah atas dan } \\
\text { menengah bawah }\end{array}$ & 123,753 & 0.60 & 74,252 & 5 & 371,259 \\
\hline 10 & Pergudangan 1 & 80,075 & 0.60 & 48,045 & 2 & 96,090 \\
\hline 11 & Pergudangan 2 & 132,870 & 0.60 & 79,722 & 2 & 159,444 \\
\hline 12 & pergudangan 3 & 67,371 & 0.60 & 40,423 & 2 & 80,845 \\
\hline
\end{tabular}

Sumber: Hasil Analisis 2017 


\subsection{Konsep Desain Kawasan TOD}

4.3.1. Konsep Desain Stasiun

Konsep desain bangunan stasiun pada Stasiun Semarang Tawang adalah sebagai berikut: bangunan Stasiun Semarang Tawang merupakan bangunan 3 lantai, dimana pada gambar potongan dibawah terlihat bahwa pemanfaatan lantainya sebagai berikut: Lantai 1 untuk 6 track at grade, Lantai 2 untuk 4 elevated track (2



Gambar 7. Site Plan Stasiun Semarang Tawang (Sumber: Hasil Analisis 2017) kereta JKT-SBY, 2 kereta Argo), dan Lantai 3 untuk sirkulasi penumpang.

Sedangkan untuk perletakan Jalur Rel Kereta Api (Track Lay Out) di Stasiun Semarang Tawang sebagai berikut: di lantai 1 terdapat 7 jalur kereta, di Lantai 2 terdapat 4 jalur kereta, dengan 2 jalur paling kiri adalah untuk kereta cepat jurusan JakartaSurabaya.

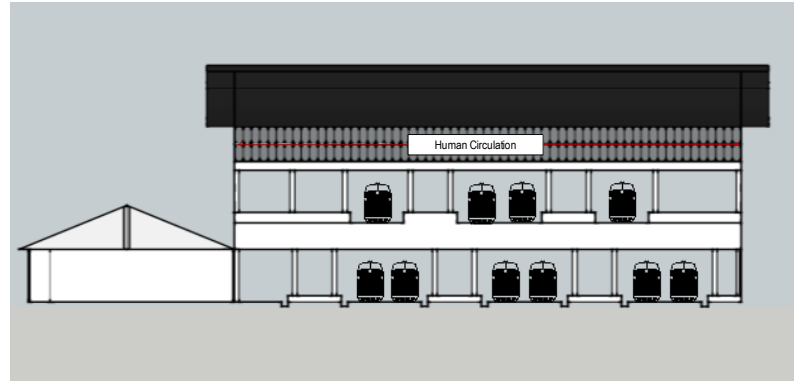

Gambar 8. Potongan Stasiun Semarang Tawang (Sumber: Hasil Analisis 2017)

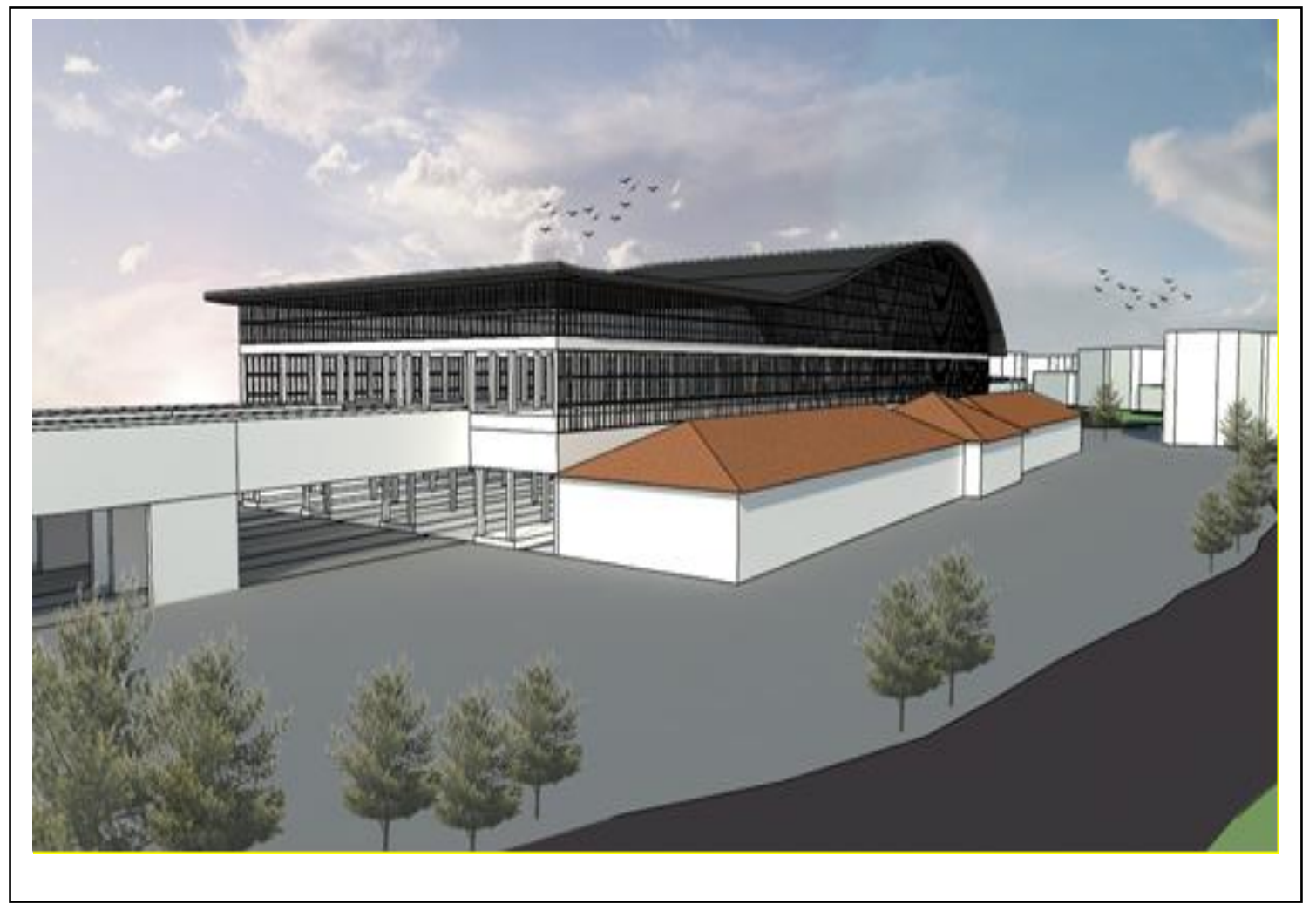

Gambar 9. Facad Stasiun Semarang Tawang

(Sumber: Hasil Analisis 2017) 


\subsubsection{Konsep Desain Kawasan TOD Stasiun Semarang Tawang}

Konsep desain pengembangan kawasan TOD Semarang Tawang adalah sebagai berikut.

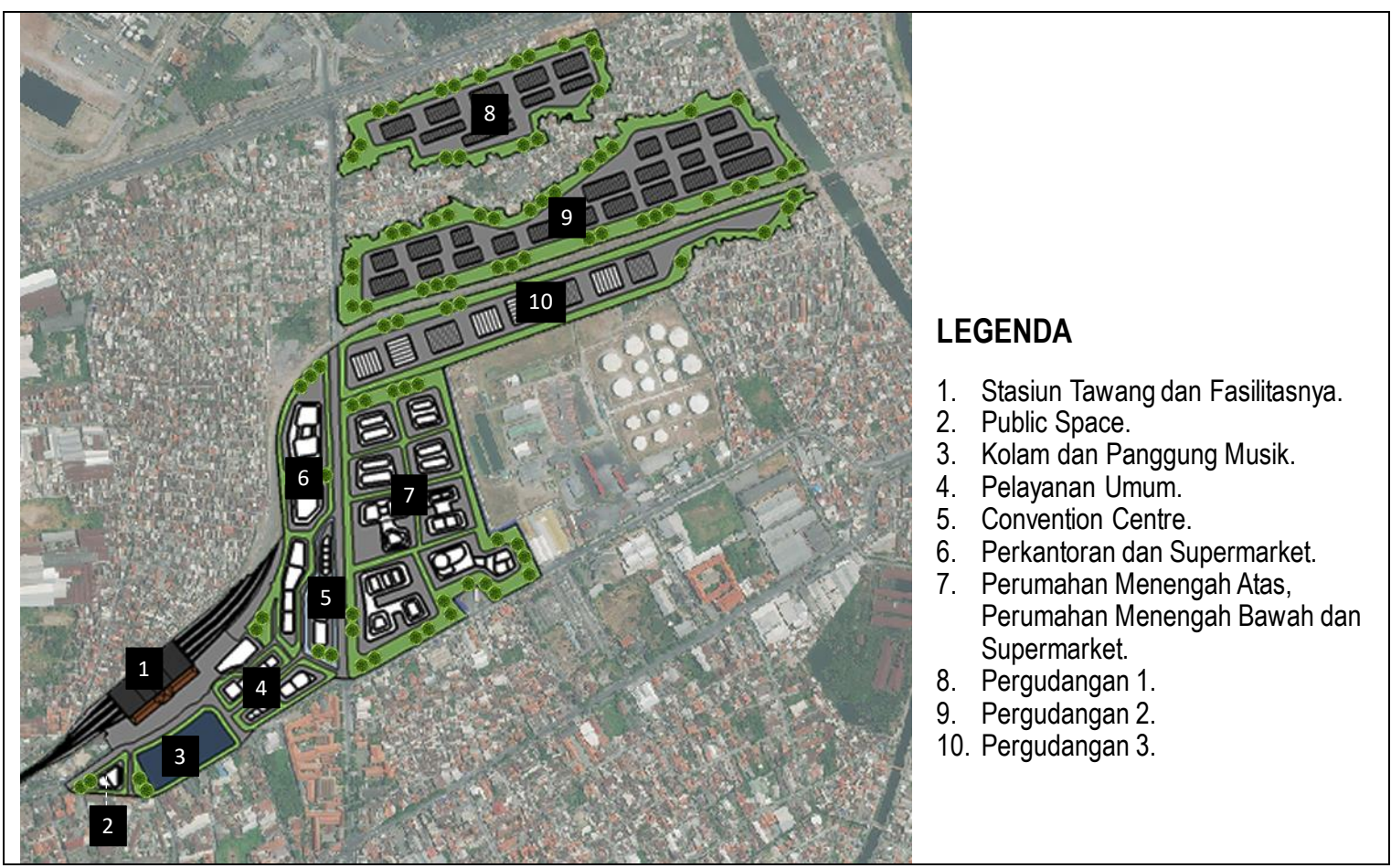

Gambar 10. Konsep Desain Pemanfaatan Lahan Kawasan TOD Semarang Tawang

(Sumber: Hasil Analisis 2017)

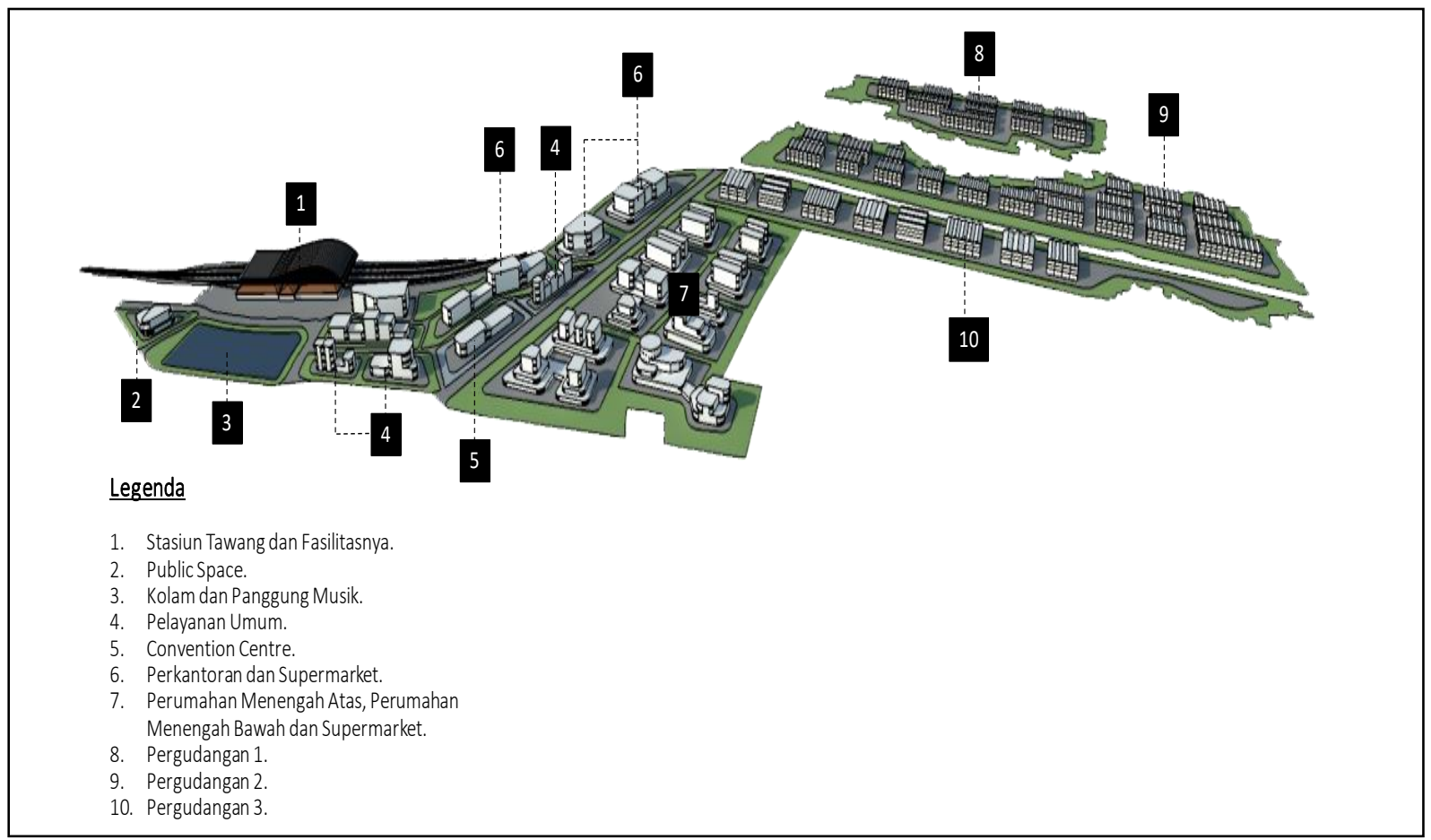

Gambar 11. Perspektif Kawasan TOD Stasiun Semarang Tawang

(Sumber: Hasil Analisis 2017) 
Luas lahan keseluruhan yang dipakai untuk Kawasan TOD Stasiun Semarang Tawang adalah $546.702 \mathrm{~m}^{2}$, yang terdiri dari:

a. Stasiun Tawang dan Fasilitas: $44.635 \mathrm{~m}^{2}$.

b. Public Space: $4.836 \mathrm{~m}^{2}$.

c. Kolam dan Panggung Musik: $18.471 \mathrm{~m}^{2}$.

d. Pelayanan Umum: $10.124 \mathrm{~m}^{2}$.

e. Parkiran Stasiun: $6.951 \mathrm{~m}^{2}$.

f. Convention Centre: $8.513 \mathrm{~m}^{2}$.

g. Pelayanan Umum: $3.677 \mathrm{~m}^{2}$.

h. Perkantoran - Supermarket: $41.480 \mathrm{~m}^{2}$.

i. Perumahan Menengah ke Atas, Perumahan Menengah ke Bawah, dan Supermarket: total $123.753 \mathrm{~m}^{2}$.

j. Pergudangan: $284.262 \mathrm{~m}^{2}$. Gambar 11 menunjukkan perspektif Kawasan TOD Stasiun Semarang Tawang.

\section{KESIMPULAN}

a. Stasiun Semarang Tawang masih memungkinkan untuk dikembangkan sebagai bagian dari Kawasan TOD Stasiun Semarang Tawang dengan memanfaatkan perencanaan berbagai moda transportasi yang terhubung satu sama lain.

b. Keberadaan Stasiun sebagai Kawasan $T O D$ yang berada pada daerah ancaman bahaya rob memungkinkan untuk dikembangkan dengan memperhatikan konstruksi pondasi yang mencapai kedalaman tanah keras dan pengaturan drainasi makro.

c. Pengembangan Kawasan TOD Stasiun Semarang Tawang memungkinkan dilakukan dengan bekerjasama antara Pemerintah Daerah, PT.KAI, Kementerian Perhubungan dan Swasta.

d. Perencanaan lebih detil diperlukan untuk mendapatkan gambaran yang lebih pasti desain dan struktur bangunan, perhitungan pembiayaan serta bentuk kerjasama dalam pembangunan dan pengelolaannya.

\section{DAFTAR PUSTAKA}

BPPT. 2017. Pra Studi Kelayakan untuk Pengembangan Kereta Cepat Jakarta Surabaya (tidak dipublikasikan).

Dirjen Perkeretapian. 2013. Studi Pembangunan Jalur Ganda Layang Semarang (tidak dipublikasikan).

National Academies of Sciences, Engineering, and Medicine. 2004. Transit-Oriented
Development in the United States: Experiences, Challenges, and Prospects. Wahington, D.C.: The National Academies Press. https://doi.org/10.17226/23360.

Peraturan Menteri ATR-BPN No. 16 tahun 2017 tentang Pedoman Pengembangan Kawasan Berorientasi Transit.

Peraturan Menteri Perhubungan RI No. PM.29 Tahun 2011 tentang Persyaratan Teknis Bangunan Stasiun Kereta Api.

Peraturan Menteri Perhubungan RI No. PM.48 Tahun 2015 tentang Standard Pelayanan Minimum Angkutan Orang dgn Kereta Api.

RDTR Kecamatan Tanjung Mas dan RTRW Kota Surabaya Tahun 2014-2034

R. Kasfari, B. Yuwono, and M. Awaluddin. 2017. Pengamatan Penurunan Muka Tanah Kota Semarang. Jurnal Geodesi Undip, Vol. 7(1): 120-130, Jan. 2018. [Online] 